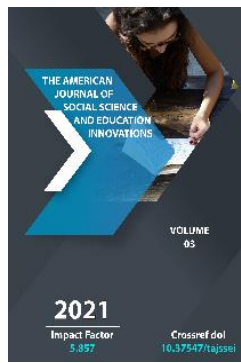

\title{
Issues Of Artistic Concept In Contemporary Uzbek Poetry
}

Berdiyeva Zulayxo

Master's Degree Student, Karshi State University, Karshi, Uzbekistan

Journal Website:

https://theamericanjou

rnals.com/index.php/ta

jssei

Copyright: Original content from this work may be used under the terms of the creative commons attributes 4.0 licence.

\section{ABSTRACT}

This scientific article focuses on the importance of the concept of art in modern Uzbek poetry. This article is about the works of our talented poets Zebo Mirzo and Halima Ahmedova, who are currently working in the field of our literature. The scientific significance of the article is that it focuses on the main ideas and goals of contemporary poetry.

\section{KEYWORDS}

Concept, Artistic Concept, Zebo Mirzo, Halima Ahmedova, Mother, Beautiful Suffering of the Years, Queen of the Night Night Pearls.

\section{INTRODUCTION}

Modern Uzbek poetry has a significant place in our literature. Today, there are many talented poets and poetesses in the field of poetry and lyricism. In the Uzbek poetry of the independence period, the best works of Usmon Azim, Khosiyat Bobomurodova, Halima Khudoiberdiyeva, Khurshid Davron, Aydin Khodzhieva, Zebo Mirzo, Halima Ahmedova and several other artists have a special place.
As for today's poetry, it should be noted that the main pathos of socio-political lyricism is the idea of preserving and strengthening independence. 


\section{THE MAIN PART}

The concept of art is very important in modern Uzbek poetry. First of all, what is the concept? Let's answer the question. Concept - (lat. Concepio- complex, system) 1) a system of views, a system of principles, a certain way of understanding, comprehending and interpreting facts and events, a basic point of view; 2) in literature - the main idea of work. In modern literature, the concept of art expresses the essence of the work of art, the "me" of the creator. However, a work of art, the concept of which in some cases may be broader than the author's subjective views. Sometimes the author contradicts the purpose, but in essence, the work, according to its concept, belongs to the artistic and aesthetic world of the author. The concept of the lyrical work is emphasized and clearly expressed, depending on the spiritual level of the student, the historical context. In the literature, according to the nature of human harassment, the concept is a whole $[2,3]$. For example, it can be a concept of a particular artist or a concept of a real work of art.

In lyrical works, the concept emerges as a mechanism-method of the artist's understanding of life through the artisticaesthetic, figurative world. In general, the concept of art determines the place of work, the product of creativity in the history of art, literature, and culture, and the degree of its impact on the student body. If we look at the works of Zebo Mirzo and Halima Ahmedova, the main artistic concept in their work is reflected in the new metaphors that they have introduced into poetry, their style and their poems in a new spirit.

In Zebo Mirzo's lyrics, the heart is one of the main themes. The poet says of the heart: The mind is a force that sometimes misleads, and destroys all that is accumulated in life with intelligence, composure, and patience in the face of adversity [1].
If he rebels, you can't control him. He will guide you. At times, you may not be able to explain yourself in a special way. You don't even understand yourself. But no matter what anyone says about you, living with your heart is a gift from God. Zebo Mirzo's first collection of poems, "Tun malikasi" ("Queen of the Night"), also contains wonderful lyrical poems. Love is the main theme in the poet's work. In her poems, the poet sings about love on high curtains $[3,4]$. This will increase the value of the feelings of love in the hearts of every poet. The main artistic concept in Zebo Mirzo's lyrics is reflected in the poet's ideas, in the places where he expresses his anguish in bright lines, what he means by his poems. There is a charm in the poems of the poet. Reading these poems, one involuntarily falls in love with the world of poetry. This is clearly reflected in the poem "Onamga" ("To my mother").

“Onamga”

Oq sochlari oppoq tun uning,

Umri halol ishqqa bayroqdir.

Oh, yuzlari dunyoyi dunning

Go'zalidan chiroyliroqdir.

(Bo'lolmadim hassasichalik),

Otam dardin ko'targan mohim.

Ushoqqina onam ko'ngliga

Bir hovuch nur bergin, ilohim!

O‘zi potrab chiqqan chashmaday

Yoningizdan oqdimu ketdim.

O’zgalarga daryo tutdimu,

Oh, onam-a, sizni unutdim.

Qaldirg‘ochlar mendan yaxshiroq, 
Baxt to'kadi hur quchog'iga.

Men ham uning tirnog‘imanu,

Arzimayman, lek tirnog'iga.

Ismaloqlar bo'yini tarab,

Bahor shoshsa yurgan joyiga,

Rabbim meni gul qilib yarat,

Hech bo'Imasa uning poyiga!..

There is no one who has not shed tears after reading the above lines. In this work, the poet describes her love for her mother, how honorable she is, that it is both a duty and an obligation for children to serve her, in such a bright, exciting and moving way. Zebo Mirzo also writes about the subtleties of women's love in his poems. The uniqueness of a woman's love is that no matter how strong, no matter how fiery, it does not speak openly about fiery feelings.

No matter how delicate a woman's heart is, it can hide fiery feelings. She is relieved only by absorbing the words, secrets, and experiences she has not told anyone into a great miracle of God called poetry. The following poem is also a sincere confession of a woman's love. This poem is about the endless sufferings and days of exile, when a representative of the subtle world misses his wound.

Sahrolar bag'rida adashgan...

Sahrolar bag'rida adashgan,

Iliq yomg‘irlarday yog‘sayding.

Namiqqan tuproqlar ko'ksida

Mag'fuz giyohlardek uyg'onsam...

Soyang tushib o'tsa nigohlarimga

Qo'ling topib borsa qalbimni.
Ovozing sachragan havoga

Shivirlab bossaydim labimni!

Bersayding ruhimga tiriklik

Ko'zlaring bir to'la nurini,

Yellar og‘ushida chayqalgan

Behush maysalarning umrini...

Yiqilsam bag'ringga yiqilsam,

Yuragingga yetarmi yo'lim?

Oqib borayapman umringga,

Qo'llarimdan ushla sevgilim.

Every reader who reads the above poem, which reflects the spirit of the lyrical hero in a very impressive way, will be immersed in an ocean of involuntary fantasies. The lines drawn in the poem show how delicate and beautiful a woman's heart is that she is a very charming creature. He does not always express his feelings. This is especially true of our Uzbek women. The idiosyncrasies of the women of the East are clearly reflected in the above verses. This is one of the main features of conceptual features of Zebo Mirzo's work. The artistic concept of Halima Ahmedova's work also reflects several meanings, such as the poet's feelings, experiences, patriotism, and femininity [4-6]. As a person becomes spiritually cleansed and purified, he comes to know the God in his heart. The poet tries to describe this process in his poems. He wants to get away from the worries of the world for a moment and feel like a part of God. The following poem also talks about the fate of man, what fate has prepared for him.

\section{Derazamni ochdim...}

Derazamni ochdim shalabbo kunga,

Qismat nelarnidir hal qilardi, hal 
Xudo, pok nafasing tegdi ko'ksimga,

Osmonning yuragi erigan mahal

Ketgim kelaverdi, bilmayman qayga,

Umrimdagi ulkan sukutni buzib.

Ship-shiydom daraxtga o'xshardi ko'nglim-

Mevalarin kimdir olgandir uzib.

Ketgim kelayapti bilmayman qayga,

Va qayda men kutgan lojuvard sahar...

Ketsam, adashaman o'zimda o'zim,

Ayanchli g'ofilman ketmasam agar...

Va ketdim haqiqat darichasini,

Chertgan shabbodalar yoniga ketdim.

Osmon va zaminning ohi tutashgan,

Ufqning qirmizi qoniga ketdim...

Qayg‘u to'lqinidaan mast bo'ldi ruhim,

Daryolar ruhiga ruhimni ekdim.

Devona ko'nglimni telba ko'nglimni,

Qushlarnig ko'ziga aldab berkitdim.

Derazamni ochib shalabbo kunga,

Negadir qo'llarim ma’yus yig'ladi.

Usti boshi bo'kkan, hol bo'lgan dunyo,

Dilimdagi olov nomin bilmadi.

Derazamni ochdim shalabbo kunga.

The conceptual meaning, clear from the above lines, is that the lyrical hero is depicted as the only Savior of the spiritual world, his worldview, in order to overcome the trials that fate has set for him, so that he relies primarily on Allah, so that Allah will achieve peace of mind. Halima Ahmedova's poem "Yillar tuhfa qilgan go'zal iztirob" ("The Beautiful Suffering of the Years") is also deeply ingrained in the hearts of readers. It is no exaggeration to say that this poem is one of the flowers of the poet's work. Halima Ahmedova's artistic concept is reflected in every work of art.

\section{CONCLUSION}

In short, the concept of art is very important in modern poetry. In this regard, the lyrics of Zebo Mirzo and Halima Ahmedova are very different from the works of artists working in the modern literary process in terms of the artistic concept. Although we have listed for you the characteristics of our personal views and opinions, we can find many more small features in it. Every artistic detail in the works of poets has its own place. In general, we see that in every product there is a certain aspect of the artistic concept.

\section{REFERENCES}

1. Halima Ahmedova. (2014). Dil ustiga ko'prik qurib. Xurshid Davron kutubxonasi.

2. S.Mirvaliyev, R.Shokirova. (2016). O'zbek adiblari. Toshkent.C'afur G'ulom nomidagi adabiyot va san'at nashriyoti.

3. Tunggi marvaridgullar. Kitob dunyosi gazetasi. 2018-yil 20-iyun.

4. Halima Ahmedova. (2016). Yashil. Toshkent. O'zbekiston.

5. Zebo Mirzo. (2021). Yangi she'rlar. Tafakkur.

6. Djuraeva, D. D., \& Berdiyeva, Z. M. (2016). Cultural heritage as a factor of human development (on the example of Uzbekistan). Ученый XXI века, 23. 